\title{
Developing sustainable strategies with system dynamics
}

Article

Accepted Version

Lane, D., Strohhecker, J. and Größler, A. (2012) Developing sustainable strategies with system dynamics. Systems

Research and Behavioral Science, 29 (6). pp. 541-546. ISSN 1099-1743 doi: https://doi.org/10.1002/sres.2147 Available at https://centaur.reading.ac.uk/67390/

It is advisable to refer to the publisher's version if you intend to cite from the work. See Guidance on citing.

Published version at: http://onlinelibrary.wiley.com/doi/10.1002/sres.2147/abstract

To link to this article DOI: http://dx.doi.org/10.1002/sres.2147

Publisher: John Wiley \& Sons, Ltd

All outputs in CentAUR are protected by Intellectual Property Rights law, including copyright law. Copyright and IPR is retained by the creators or other copyright holders. Terms and conditions for use of this material are defined in the End User Agreement.

\section{www.reading.ac.uk/centaur}

\section{CentAUR}

Central Archive at the University of Reading

Reading's research outputs online 
This document is the pre-peer reviewed version of the following article:

Lane DC, Strohhecker J and Größler A. 2012. Editorial - Developing Sustainable Strategies with System Dynamics. Systems Research and Behavioral Science 29(6): 541-546.

which has been published in final form at:

http://onlinelibrary.wiley.com/doi/10.1002/sres.2147/abstract

Note that the published version has some differences from the version here. In all cases, the published version takes precedence.

If you wish to cite the ideas in this paper then please cite the version published in SR\&BS, NOT this version.

Please contact the Corresponding Author if you have any queries.

\section{Guest Editorial}

\section{Developing Sustainable Strategies with System Dynamics}

Selected papers from the Fifth European System Dynamics Workshop, at the Frankfurt School of Finance \& Management, Germany

David C. Lane ${ }^{1 *}$, Jürgen Strohhecker ${ }^{2}$ and Andreas Größler ${ }^{3}$

1 Henley Business School, England

2 Allgemeine Betriebswirtschaftslehre, Produktionswirtschaft und Controlling, Frankfurt School of Finance \& Management, Germany

3 Nijmegen School of Management, Radboud University Nijmegen, The Netherlands

\section{INTRODUCTION}

Contributions from the field of system dynamics modelling make up this special issue of Systems Research and Behavioral Science. The use of system dynamics-based analysis to issues of sustainability was the focus of the Fifth European System Dynamics Workshop (EUSDW-V). Held at the Frankfurt School of Finance \& Management, Germany in March 2011, this

* Correspondence to: Prof David C Lane, Henley Business School, Whiteknights, Reading, RG6 6UD, England. E-mail: d.c.lane@ henley.ac.uk 
Lane, Strohhecker \& Größler - Developing Sustainable Strategies with System Dynamics

workshop involved work from which the papers included in this issue have been selected and developed.

As a venue for a workshop which drew together system dynamicists from across Europe, Frankfurt am Main was a very appropriate setting. Thanks to its location at the heart of Europe and Germany, Frankfurt is an important traffic hub and can be reached by visitors extremely easily. However, Frankfurt is more than its airport (which is the third largest airport in Europe). It is also the most international city in Germany, the largest financial centre on the continent, the historical city of coronations, the city of the writer, politician and philosopher Goethe, the site of the first freely-elected legislative body in Germany (in the Paulskirche) and the seat of European Central Bank and, of course, the location of the world-reknown Frankfurt Book Fair. With only about 700,000 inhabitants, Frankfurt advertises itself as the smallest metropolis in the world.

The Rhein-Main area including Frankfurt am Main is also a high-capacity scientific, research and higher education location. It offers a broad range of public and private universities as well as business schools. Frankfurt School of Finance \& Management is a private research-based business school, its research, teaching and consulting activities covering every aspect of business, management, banking and finance.

With its central European location and strong showing in the area of SD, Frankfurt offered an excellent location in which the European system dynamics community could meet again via the mechanism of the continuing workshop series. The first such event resulted from the work of Peter Milling and Andreas Größler at the Universität Mannheim, Germany. In 2003 they organised a pan-European meeting of SD researchers. A further result was a special issue of this journal on the topic of 'Rationality in System Dynamics: Modelling Human and Organizational Decision Making' (Lane, Größler \& Milling, 2004). The next workshop meeting took place in 2005 at Radboud University, Nijmegen in The Netherlands. The theme was 'System Dynamics in Organizational Consultation: Modelling for Intervening in Organizations' (Lane, Rouwette \& Vennix, 2006). The University of St. Gallen in Switzerland was home in 2007 to a third workshop organised around the theme of 'Theory Building with System Dynamics' and which produced a further special issue (Lane \& Schwaninger, 2008). The fourth workshop, hosted by the University of Palermo, Italy in 2009 took the theme 'Public Sector Applications of the System Dynamics Approach' (Lane, Bianchi \& Bivona, 2010).

Figs. 1 (See published version)

Old and new spires in the skyline of Frankfurt-am-Main

The Frankfurt meeting was therefore the fifth in a sequence of workshops which afford an opportunity for system dynamics researchers spread across Europe to meet with each other and discuss their ideas and work. To help achieve this aim, the Mannheim meeting utilised a noteworthy format, one which has been employed on subsequent occasions. Local organisers alight upon a theme and colleagues known to be active in that area are invited. What results is presentations ranging from projects in an advanced state of development, to research 
topics beginning to emerge. Written articles from the speakers are circulated to participants before the workshop in order to encourage full participation. Additionally, a 'Discussant' is allocated to each paper, allowing that person to adopt the role of detailed commentator. The hosts for EUSDW-V were Jürgen Strohhecker and Andreas Größler. At Frankfurt School of Finance \& Management Jürgen Strohhecker has been teaching system dynamics since 2002. As part of the bank management concentration in the School's Master of Finance program, the course applies system dynamics to the development and implementation of business strategies. Additionally, since the foundation of the German Chapter of the international System Dynamics Society, Frankfurt School regularly hosts afternoon and evening events that are open to everybody interested in system dynamics modelling and simulation. System dynamics based research at Frankfurt School focuses on dynamic decision making, stock and flow thinking and experimental system dynamics.

The second conference host, Andreas Größler, teaches and researches at Radboud University Nijmegen in the Netherlands, where the second European workshop took place. He is an adjunct faculty member of Frankfurt School of Finance and Management. The System Dynamics Group at Radboud University conducts research in the areas of dynamic decision making, participative modelling, and behavioural operations management. The group is part of a network of universities that established the European Master in System Dynamics study programme, whose first participants graduated at the time of this writing.

The workshop was held over a day and a half. As participants gathered, the evening before the workshop was used as an opportunity to visit the well-preserved old town of the Sachsenhausen district and sample "Äppelwoi", the local dialect word for "Apfelwein", or cider. The workshop itself was held in the excellent facilities of the Frankfurt School of Finance \& Management, located close to the centre of the city and only a few minutes' walk from the Main. First, authors gave a talk on their work. This was followed by detailed remarks from the designated discussants. Finally, all workshop participants offered comments, questions and advice.

All of the European workshops have been events that stand or fall on their own terms. However, some of the work was then continued into the refereeing process of this journal. In consequence, the guest editors include in this special issue a selection of then papers presented at EUSDW-V, these having been developed further, in part in response to comments from workshop participants. Included here are remarks from the discussants on the research papers. They are included in order to provide a sense of the discussion at the workshop. They also serve to provide alternative treatments of the papers' topics and on the overarching workshop theme.

Fig. 2 (See published version)

Sampling "Äppelwoi" in the Sachsenhausen district of Frankfurt. 
This topic was chosen because of its broad relevance to management thinking. Managing dynamic systems in a sustainable way is a considerable challenge: ups and downs, boom and bust are found far more often in real systems than long-lasting equilibria. As a consequence, even apparently successful growth strategies work only for some restricted time span. The finite nature of all resources prevent systems from growing forever. Decreasing resource availability produces 'frictional effects' and eventually growth encounters a limit, a ceiling of some sort which makes further growth impossible. Indeed, if the key resources were deliberately or accidentally damaged during the growth phase then a boom and bust pattern emerges as the growth stalls and reverses into collapse. However, once growth has reached a 'plateau' of some sort, with a better strategy, life on that plateau can perhaps be sustained for an extended period.

When system dynamics was created the term 'sustainable development' was not yet commonly used. It was left to the World Commission on Environment and Development in 1987 chaired by Gro Harlem Brundtland to express the idea of sustainability into the now famous words: sustainable development ensures that "it meets the need of the present without compromising the ability of future generations to meet their own needs" (World Commission on Environment and Development, 1987).

In terms of a broad, environmental interpretation of this aspiration, system dynamics modelling has made significant contributions via World Dynamics and Limits to Growth (Forrester, 1971; Meadows et al., 1972). Such work "has been instrumental in shaping public thinking on environmentalism, development, pollution and resource restrictions ... insights on the aim of caring for the environment and the need to make trade-offs between long-term versus short-term effects have an important place in environmentalist thinking today and [Forrester's] original model is the founding work of global modelling" (Lane, 2007, p. 107-8). However, developing and implementing sustainable business strategies - in the broadest sense - has been at the core of system dynamics thinking from the very beginning (Größler \& Strohhecker, 2012). In the paper that announced publically the creation of the new field, Forrester named four goals that motivated the development of the new field and these revealed its connection with the modern sustainability concept. He argued that companies could achieve sustainable development by:

1) aiming at obtaining "a better intuitive feel for the time-varying behaviour of industrial and economic systems";

(2) providing "a background showing how the major aspects of a company are related to one another";

(3) helping to "predict the future course of an existing organization";

(4) improving "the future prospects of a company"

(See Forrester, 1958, pp. 65-6).

This point having been made, it is now possible to relate more traditional 'environmentalist' ideas of sustainability with concepts of relevance to management thinking. So, on a global 
Lane, Strohhecker \& Größler - Developing Sustainable Strategies with System Dynamics

level, three operational rules suggested by Herman Daly have become widely accepted as defining the condition of ecological sustainability and thus moving from the ethical exhortations of the Brundtland definition to operationalisable steps:

- Renewable resources (such as fish, soil, and groundwater) must be used no faster than the rate at which they regenerate.

- Non-renewable resources (for example minerals and fossil fuels) must be used no faster than renewable substitutes for them can be put into place.

- Pollution and wastes must be emitted no faster than natural systems can absorb them, recycle them, or render them harmless.

(See Daly, 1991; Daly, 1996; Meadows, et al. 2004). Adapting the Daly rules to a business context, the equilibrium condition for sustainable business practice might be characterized as follows:

- Renewable business resources (such as customers, employees, brand awareness, and cash) must be used no faster than the rate at which they can be acquired or built.

- Non-renewable resources (for example rare earth elements, patents and fossil-fuel based energy) must be used no faster than substitutes for them can be put into place.

- Emissions of the business (in its broadest sense) must not exceed the absorption capacity of its relevant environment.

Less abstract as these ideas are, they still need to be crafted in specific circumstances. This insight underlies the Frankfurt workshop: whilst one may think abstractly of balancing inputs with outputs, it is necessary to consider cases in detail and propose specific policies which achieve 'sustainability'. How system dynamics can support such considerations - and across a wide range of application domains - was therefore the organising theme for the workshop.

Figs. 3 (See published version)

The workshop opens

\section{THE FRANKFURT WORKSHOP}

This special issue offers a set of contributions on the topic of sustainable strategies. These consist of research papers and discussants' comments. After this editorial, the special issue therefore contains the following:

1. The scene is set by the paper 'Implementing Sustainable Business Strategies' by Jürgen Strohhecker and Andreas Größler. Using data from a dynamic decision making experiment, they show that participants' attempts to implement a sustainable business growth strategy all too frequently produce either an overshoot and collapse dynamic, or 
Lane, Strohhecker \& Größler - Developing Sustainable Strategies with System Dynamics

considerable underperformance in terms of what could be achieved. The Discussant's Comments that follow are by Markus Schwaninger.

2. This is followed by a paper by Birgit Kopainsky, Katharine Tröger, Sebastian Derwisch and Silvia Ulli-Beer. In 'Designing sustainable food security policies in sub-Saharan African Countries' they show that strategies aimed at creating sustained take-up amongst Malawi farmers of improved maize seed varieties must be based on a clear understanding of the mechanisms of trust-building if they are to be effective. David Lane provides a commentary.

3. The third paper 'Mapping Maritime Sustainability Issues with Stakeholder Groups' is by Nuno Videira, Rita Lopes, Paula Antunes, Rui Santos and José Luís Casanova. They describe the use of a participatory modelling and the creation of qualitative maps in support of support scoping stages of an 'Integrated Sustainability Assessment' process intended to consider sustainability issues in Portugal. Etiënne Rouwette offers a commentary on the paper.

4. In 'Dynamics of Journal Impact Factors' Stefan Groesser applies the criterion of sustainability to academia itself. Using simulation modelling he consider how the assets and resources of an academic journal are best organised to improve the frequency at which articles that journal are cited. He concludes that the key resources of high quality authors and reviewers must be developed in tandem.

5. The research paper 'Metaphorical Models for Limits to Growth and Industrialisation' is by John Morecroft. He uses models of a fishing industry and of global growth and industrialisation to revisit the feedback structure of Forrester's World Dynamics model and suggests that metaphorical models are useful for interpreting puzzling phenomena concerning sustainable strategies. Jörn-Henrik Thun discusses this paper.

6. The unusual but welcome piece by Andreas J. Harbig and Craig A. Stephens was presented at the workshop as a Socratic dialogue. Their 'Sustainability for System Dynamics' asks hard questions about the field of system dynamics itself and suggests innovative ways of moving the field forward

7. The special issue closes with a record of the comments made at a special presentation; 'Ignoring Goethe: In Celebration of the Workshop Guest of Honour Peter Milling'.

We very much hope that this collection will interest researchers and practitioners in system dynamics, system science, OR/MS and environmental policy. 
Figs. 4 (See published version)

Listening to a presentation.

\section{ACKNOWLEDGEMENTS}

The guest editors would like to offer their thanks to all who made this special edition possible:All those whose organisational efforts lead to the smooth running in 2011 of the EuSDW-V workshop.

Those who anonymously acted as referees for this special edition. The refereeing process drew on the world-wide community of systems science, operational research and system dynamics researchers and we are grateful to them for their vital assistance.

Janet Larkin of the Department of Coin and Medals and Lesley Fitton of the Department of Greek and Roman Antiquities, both of the British Museum, London provided the image upon which the symbol used for the workshop series is based. The owl is taken from the reverse side of a silver tetradrachm made in Athens around 480 BC. CM 1906-11-3-2591. Copyright British Museum, London. The Athenian owl symbol for the series of European System Dynamics Workshops was designed and created by David Lane.

What is now thought of as the first European System Dynamics Workshop in Mannheim in March 2003 was the work of Andreas Größler and Peter Milling. We are grateful to them for their creation of a sound format for the workshops.

Finally, Mike Jackson and Amanda Gregory for inviting us to produce the special issue and for their constant support for the European System Dynamics workshops.

\section{REFERENCES}

Daly, H.E., 1991. Steady-state Economics, 2nd ed. Washington, D.C.: Island Press.

Daly, H.E., 1996. Beyond Growth: The economics of sustainable development Boston: Beacon Press.

Forrester, J.W., 1958. Industrial Dynamics: A major breakthrough for decision makers. Harvard Business Review, 26 (4), 37-66.

Forrester, J. W. 1971. World Dynamics. Cambridge, MA, Wright-Allen Press.

Größler, A. \& Strohhecker, J. 2012. System Dynamics and Sustainability. C.N. Madu \& C.-H. Kuei (eds.): Handbook of Sustainability Management, Singapore: World Scientific, 313-334.

Lane DC. 2007. The Power of the Bond Between Cause and Effect: Jay Wright Forrester and the field of system dynamics. System Dynamics Review 23: 95-118.

Lane, D.C., Größler, A. \& Milling, P.M. 2004. Rationality in System Dynamics: Modelling human and organizational decision making, Systems Research \& Behavioral Science, 21(4): 313317. 
Lane, Strohhecker \& Größler - Developing Sustainable Strategies with System Dynamics

Lane, D.C., Rouwette, E.A.J.A. \& Vennix, J.A.M. 2006. System Dynamics in Organizational Consultation: Modelling for intervening in organizations, Systems Research \& Behavioral Science, 23(4): 443-449.

Lane, D.C. \& Schwaninger, M. 2008. Theory Building with System Dynamics: Topic and research contributions, Systems Research \& Behavioral Science, 25(4): 439-445.

Lane, D. C., Bianchi, C \& Bivona, E. 2010. Public Sector Applications of the System Dynamics Approach. Systems Research and Behavioral Science 27(4): 355-360.

Meadows, D. H., D. L. Meadows, D. L., Randers, J. \& Behrens, W. W. 1972. The Limits to Growth: A report for the Club of Rome's project on the predicament of mankind. London, Earth Island.

Meadows, D.H., Randers, J. \& Meadows, D., 2004. Limits to Growth: The 30-year update White River Junction: Chelsea Green.

World Commission on Environment and Development, 1987. Our Common Future Oxford: OUP. 
Lane, Strohhecker \& Größler - Developing Sustainable Strategies with System Dynamics

N.B. This list of contents is not part of the Editorial

\section{Developing Sustainable Strategies with System Dynamics}

\section{Selected papers from the Fifth European System Dynamics Workshop, at the Frankfurt} School of Finance \& Management, Germany

Guest Editors: David C. Lane, Jürgen Strohhecker and Andreas Größler

\section{Contents of the Special Issue}

Systems Research and Behavioral Science, 2012, Volume 29 Number 6

541 Guest Editorial: Developing Sustainable Strategies with System Dynamics - David C. Lane, Jürgen Strohhecker and Andreas Größler

547 Implementing Sustainable Business Strategies - Jürgen Strohhecker and Andreas Größler

571 Implementing Strategies: The Strohhecker-Groessler Study and the Need for a New Way of Thinking - Markus Schwaninger

575 Designing Sustainable Food Security Policies in Sub-Saharan African Countries: How Social Dynamics Over-Ride Utility Evaluations for Good and Bad - Birgit Kopainsky, Katharine Tröger, Sebastian Derwisch and Silvia Ulli-Beer

590 What Is a 'Policy Insight'? - David C. Lane

596 Mapping Maritime Sustainability Issues with Stakeholder Groups - Nuno Videira, Rita Lopes, Paula Antunes, Rui Santos and José Luís Casanova

620 Does Group Model Building Work? Evidence from and Comments on the Paper by Videira et al. - Etiënne A. J. A. Rouwette

624 Dynamics of Journal Impact Factors - S. N. Groesser

645 Metaphorical Models for Limits to Growth and Industrialization - John D. W. Morecroft

667 Are Metaphorical Models Really Helpful? Comment on the Paper by Morecroft - JörnHenrik Thun

669 Sustainability for System Dynamics: A Socratic Dialogue - Andreas J. Harbig and Craig A. Stephens

674 A Commonwealth of Learning: In Celebration of the Workshop's Guest of Honour Peter Milling - David C. Lane, Jürgen Strohhecker and Andreas Größler 